\title{
A histeria em Freud e Flaubert ${ }^{1}$
}

\author{
Sérgio Scotti \\ Universidade Federal de Santa Catarina
}

\begin{abstract}
Resumo
Este artigo passa em revista o percurso de Freud nos seus textos sobre a histeria e outros correlatos e, seguindo a sugestão do inventor da psicanálise, dirige-se à consideração da personagem de um clássico da literatura, "Madame Bovary", de Flaubert, buscando apontar os traços estruturais da histeria a partir da trajetória tanto da personagem mencionada quanto da consideração de outras obras do mesmo autor.
\end{abstract}

Palavras chave: Histeria, Literatura, Psicanálise.

\begin{abstract}
Hysteria in Freud and Flaubert. This article reviews Freud's course in his texts about hysteria and others related to it, and, following the suggestion of the inventor of psychoanalysis, intends to consider the character of a literary classic, Flaubert's "Madame Bovary", aiming to point out the structural aspects of hysteria from the course of both, the character already mentioned, and the consideration of other books by the same author.
\end{abstract}

Key words: Hysteria, Literature, Psychoanalysis.

$\mathrm{E}$ $\mathrm{m}$ vez de uma resenha histórica das obras de Freud dedicadas à histeria, procuraremos aqui seguir um percurso, o percurso de Freud na compreensão da histeria, o que exigirá a consideração de outras obras de Freud não relacionadas diretamente à histeria. Quando seguimos tal percurso, observamos que as questões que Freud coloca sobre a histeria, se confundem com as que ele coloca sobre a mulher.

Seja porque a histeria fosse mais freqüente entre as mulheres, seja porque, como para todo homem, a mulher era um enigma para Freud, o fato é que podemos observar, até em suas últimas obras, o eco da pergunta: "O que quer a mulher?"

Freud, quando começou a tratar as primeiras histéricas de que nos deu notícia - Emmy de N., Lucy R., Catalina, Isabel de R. - estava fundamentalmente preocupado com a questão do trauma. Embora muito já se tenha falado a respeito do engano de Freud - e ele mesmo foi o primeiro a reconhecê-lo - sobre a veracidade das cenas de sedução sofridas pelas histéricas, o pai da psicanálise já destacava então que o traumático não era a sedução em si, mas a recordação da cena. As histéricas sofriam então de reminiscências. Isso porque Freud reconheceu que a sexualidade humana acontecia em dois tempos marcantes: a infância e a puberdade.

A cena então era de natureza sexual, infantil; sua recordação traumática, na adolescência, era provocada por um evento que tinha um enlace lógico com a cena infantil: uma cena em que o sujeito infantil era a-sujeitado, passivo.

Freud nos dá belo exemplo deste processo, típico da histeria segundo ele, no "Proyecto de una Psicologia para Neurologos" (Projeto de uma Psicologia para Neurólogos, 1895/ 1973), na segunda parte, referente à Psicopatologia (Compulsão Histérica), onde Emma, uma paciente que não consegue entrar sozinha em lojas, se recorda de uma cena vivida aos doze anos em que, ao entrar numa loja e, ao ver dois rapazes rindo entre si, sai correndo, presa de uma espécie de susto. As associações da paciente levam-na a pensar que os rapazes riam do vestido dela e que um deles a atraiu sexualmente. $\mathrm{Na}$ continuação da análise, surge uma segunda lembrança dos oito anos de idade em que, por duas ocasiões seguidas, Emma vai a uma pastelaria, mesmo depois de que, na primeira vez, o pasteleiro, com riso sardônico, lhe tivesse tocado os órgãos genitais por sobre o vestido.

O enlace dos elementos vestido, riso e atração sexual revela que a angústia de estar sozinha numa loja se refere ao medo inconsciente de que os rapazes repetissem o atentado perpetrado pelo pasteleiro, afeto angustioso que surge após a entrada da paciente na puberdade e que não esteve presente na situação original.

Na maioria dos casos, ressaltava Freud, eram várias as cenas traumáticas e não somente uma cena infantil de sedução sexual; daí a distinção entre "histeria traumática" e "his- 
teria comum" já feita nos "Estudios Sobre la Histeria" (Estudos Sobre a Histeria, 1895/1973). A etiologia sexual da histeria e das neuroses em geral adquiriu tal peso para Freud, que ele chegou a dedicar-lhe trabalho específico: "La Sexualidad en la Etiologia de las Neurosis" (A Sexualidade na Etiologia das Neuroses), editado em 1898 (1898/1973).

Mas, é sempre bom lembrar, as reminiscências de que sofriam as histéricas, eram inconscientes, ou seja: as histéricas sabiam, mas não sabiam que sabiam; ou elas se lembravam, mas não sabiam disso ou não queriam saber nada disso. Não queriam saber nada de suas lembranças da infância e, nem tampouco, de suas fantasias não tão infantis assim, fantasias de amor em geral. Poderíamos dizer, então, que as histéricas sofriam de amor também, mas de um amor recusado à consciência, um amor que, embora consciente um dia, fora recalcado, reprimido. Veja-se o caso de Isabel de R. nos La Etiologia de la Histeria (Estudos sobre a Histeria, 1895/1973): eram suas fantasias de amor com seu cunhado, junto ao leito de sua irmã enferma, que a faziam padecer de seus sintomas.

É da fantasia que Freud passa a se ocupar cada vez mais com suas histéricas, até que, em setembro de 1897 (1897/ 1973), numa carta a Fliess, ele revela que já não mais acredita em seus neuróticos.

É, portanto, à fantasia mais do que a uma eventual sedução, que Freud passará a dar maior importância na compreensão da produção de sintomas das histéricas, como no famoso caso Dora (1905/1973), no qual, apesar disso, Freud dará importância indevida a uma cena de tentativa de sedução em que o sr. K. beija Dora, anos antes da não menos famosa cena à beira do lago.

Identificado ao sr. K., como supõe Lacan (1951/1998), Freud, pelos seus preconceitos, não percebe o amor "homossexual" de Dora pela sra. K (Freud, 1905/1973). Numa nota de rodapé, no epílogo do relato do caso, Freud reconhece sua falha e, ao mesmo tempo, ressalta a importância dos sentimentos homossexuais nas neuroses. Algumas páginas antes, ele chega mesmo a imaginar que, se fosse mais "caloroso" com Dora, esta talvez não abandonasse o tratamento, dando-nos a impressão de que Lacan estava realmente certo.

Não se trata aqui de analisar os erros de Freud, mas, quando nos perguntamos por que Freud ou qualquer analista escolhem este ou aquele caso para comunicar, especialmente quando se trata de um caso mais ou menos falhado, vem-nos à mente a idéia de que é mesmo o que falha que motiva o relato do caso. E o que falha em Freud é o reconhecimento do amor homossexual da histérica ou, como veremos, o amor à mãe.

Após destacar, novamente, em "Fantasías Histéricas y su Relación con la Bisexualidad" (Fantasias Histéricas e sua Relação com a Bissexualidade, 1908/1973), o papel das fantasias onanistas de caráter homossexual, a cegueira de Freud, ao nosso ver, aparece novamente num outro relato, dessa vez não dedicado a um caso de histeria, mas de homossexualismo feminino, "Sobre la Psicogénesis de un Caso de Homosexualidad Femenina" (Sobre a Psicogênese de um Caso de Homossexualidade Feminina, 1920/1973). Neste caso, Freud, ainda preso a uma compreensão insuficiente do desenvol- vimento do Édipo na mulher, o vê ainda muito sob a perspectiva masculina. Isso faz com que, novamente aqui, ele atribua importância excessiva à relação da paciente com seu pai.

Não percebendo a importância da fixação da mesma à mãe, Freud entende a tentativa de suicídio da jovem paciente como dupla satisfação, a do desejo de engravidar do pai e a de se autocastigar pela mesma razão, sem considerar que, ao ser surpreendida pelo pai, na rua, em companhia da amada, que por isso ameaça abandoná-la, a paciente se desespera, na verdade, com perder o amor da mãe, transferido para a amada.

Só que aqui, Freud não se deixa abandonar como o fizera no caso Dora. Parece-nos mesmo que ele atua sua resistência, ao abandonar a paciente, recomendando-lhe que procurasse uma "doutora". Freud sai, assim, de cena, dando lugar à "mãe doutora", não acreditando nos sonhos da paciente, que anunciam sua cura, através do casamento e da maternidade.

Somente, já quase ao final do relato, Freud reconhece que a homossexualidade adquirida tardiamente, como ele supunha no início do tratamento, em razão da frustração de desejos amorosos emanados do complexo de Édipo, consistia na verdade, de homossexualidade "congênita", que só veio a exteriorizar-se completamente após a puberdade. Acrescenta que tal questão talvez não fosse de grande valor, fazendo-nos pensar que fosse o principal.

Mas, por que falar de um caso de homossexualidade feminina quando se trata de considerar a histeria?

Como ponderamos no início, a histeria e o feminino se confundem em Freud. E o que junta os dois é a questão homossexual, tanto da histeria quanto da mulher. Por isso consideramos este último relato como uma espécie de encruzilhada que levará Freud à reconsideração da posição da mulher no complexo de Édipo em "Algunas Consecuencias Psíquicas de la Diferencia Sexual Anatómica" (Algumas Conseqüências Psíquicas da Diferença Sexual Anatômica, 1925/1973).

Freud já trabalhara este tema mais rapidamente em "La disolución del complejo de Edipo" (A Dissolução do Complexo de Édipo, 1924/1973), mas é, no ano seguinte, que desenvolve mais amplamente os aspectos relativos às diferenças entre o menino e a menina quanto à castração, relacionada com o complexo de Édipo. Aí conclui que, enquanto a ameaça de castração liquida o Édipo no menino, com todas suas conseqüências estruturantes, a castração, enquanto fato consumado, lança a menina no Édipo, de onde muito mais tardiamente sairá. Até mesmo questões anteriores tais como as fantasias femininas recorrentes de "Pegan a un Niño" (Batese numa Criança, 1919/ 1973), são revistas em função da castração e da inveja do pênis, o que resulta na equivalência criança $=$ clitóris

Mas, paradoxalmente, a diferenciação entre o menino e a menina, no Édipo, acabou por descobrir as semelhanças entre um e outro. Tais semelhanças vão aparecer, de forma mais clara ainda, no trabalho, "Sobre la sexualidad feminina" (Sobre a Sexualidade Feminina, 1931/1973).

Estejam as nossas especulações anteriores corretas ou não, o fato é que neste trabalho, Freud, por suas próprias experiências e pelas experiências das analistas mulheres, algumas delas nomeadas - Jeanne Lampl-de Groot, Helene 
Deutsch, Ruth Mack Brunswick e Melanie Klein - acaba por reconhecer, amplamente, a importância da vinculação da mulher à mãe e à chamada fase pré-edípica. Acaba por reconhecer também, a importância dessa vinculação para a etiologia da neurose histérica.

Neste trabalho, podemos reconhecer e encontrar alguns ensinamentos fundamentais de Freud, não somente quanto à mulher e à histeria, mas também quanto ao humano em geral. Nele, Freud nos diz que, sob o império do falo, somos todos iguais, ou seja, menina ou menino, homem ou mulher, macho ou fêmea; tais categorias não existem até a superação da fase fálica. Existem os que têm o falo e os que não o têm.

A percepção, no seu amplo sentido, da diferença entre os sexos, é uma aquisição tardia no desenvolvimento psicossexual do homem, acontecendo de maneira muito imperfeita em alguns casos, como, por exemplo, na histeria, na qual não se sabe ao certo se se é homem ou mulher, pois, aí, a lógica do falo ainda domina.

Contrariamente ao entendimento de que Freud (1931/1973) teria colocado a libido como sendo sempre masculina, cremos que o que ele nos ensina é que a libido não tem sexo:

Para a psicologia, entretanto, é indiferente se no corpo existe somente uma substância sexual estimulante, ou duas, ou um sem número delas. A psicanálise nos ensinou a manejar com uma só libido, ainda que seus fins, ou seja, seus modos de gratificação, possam ser ativos e passivos ${ }^{2}$ (p. 3087).

Embora reconheça que a libido sempre procura dominar seu objeto de forma ativa, reconhece, também, que a libido tem fins passivos, se bem que os procure de forma ativa.

$\mathrm{O}$ que se percebe é que a assimilação do masculino ao ativo nunca satisfez a Freud, que sempre mostrou muitas reservas à equivalência do par masculino/feminino = ativo/passivo.

Afora estes aspectos mais gerais, a questão da histeria, que nos interessa mais de perto, ganha novas luzes nesse trabalho sobre a sexualidade feminina e no seguinte, e derradeiro da obra de Freud sobre a mulher, em "Nuevas lecciones introductorias al psicoanalisis - La feminidad" (Novas Lições Introdutórias à Psicanálise - A Feminilidade, 1933/1973).

Nestes dois últimos trabalhos e especialmente naquele sobre a feminilidade, ele se limita a tentar dizer como surge a mulher, pelo impossível que é dizer A mulher, como demonstrará mais tarde Lacan (1975/1985). Freud, como que numa volta ao começo, lembra que como se apercebeu da falsidade das cenas de sedução das histéricas imputadas ao pai, por conta das fantasias do complexo de Édipo, dava-se conta agora de que a sedução originariamente sofrida pela menina era exercida, na verdade, pela mãe, através da estimulação dos genitais durante a higiene corporal. Tal sedução era transferida e atribuída posteriormente ao pai.

Ao mesmo tempo, Freud se dá conta de que as intermináveis queixas das histéricas tanto ao analista, quanto à própria mãe, derivavam da castração de que elas se sentiam vítimas. Dá-se conta também de que a angústia característica da histérica provém do ódio à mãe que a privou do falo. Falo que mesmo a mulher "normal", não cansará de perseguir na forma de um filho ou, até mesmo, na procura de uma análise.
Ao final de seu último trabalho sobre a feminilidade, Freud sugere que, se quisermos saber mais sobre isso, devemos basear-nos em nossa própria experiência, esperar os avanços da ciência ou perguntar aos poetas. Seguindo então sua sugestão, interrogaremos a seguir o texto de Flaubert que criou um tipo feminino extensamente conhecido: "Madame Bovary".

\section{De Freud a Flaubert}

Madame Bovary ou Emma Bovary é a personagem do romance que Flaubert levou cinco anos para compor, no qual, buscava de forma obsessiva, o ideal de uma literatura em que a mão do autor desaparecesse, tal como a mão de Deus no universo $^{3}$. Esse ideal realista notabilizou o romance dos romances como a obra mais representativa do Realismo francês, tendo exercido influência sobre escritores brasileiros, a exemplo de Aluísio Azevedo e Machado de Assis.

Gustave Flaubert nasceu em Rouen, França, a 12 de dezembro de 1821, e faleceu em Croisset, perto de Rouen, a 8 de maio de 1880. Filho de cirurgião, aos quinze anos apaixonouse por Elisa Schlésinger, mulher 15 anos mais velha que ele, casada e com um filho. Tal paixão acompanhou-o por toda vida e influenciou suas primeiras obras de caráter romântico. Após a Revolução Liberal de 1848 empreendeu viagem pela África do Norte e Oriente Próximo passando por Malta, Egito, Palestina, Líbano, Constantinopla, Grécia, Itália. Retirou-se depois para seu sítio em Croisset, dedicando seus últimos 30 anos de vida à produção literária em solidão quase total.

O suicídio, após adultério, cometido na Normandia pela mulher de um oficial de saúde serve de tema para Flaubert, que começa a publicar "Madame Bovary" em 1856 na Revue de Paris, narrativa que se transforma em livro em 1857 (1857/ 1993), após a absolvição do autor no processo em que foi acusado de "ofensa à moral pública e religiosa", no qual, em resposta à pergunta de quem teria sido o modelo do personagem, Flaubert pronunciou a frase histórica: “Madame Bovary c'est moi". Ele dedicou os últimos anos de sua vida a um romance que deixou inacabado: "Bouvard e Pécouchet" (1881/1981).

"Madame Bovary" é a trágica história de uma jovem que, aos treze anos, é levada pelo pai ao convento de Rouen, onde se delineia para nós, através da apresentação da personagem no capítulo VI, uma histérica em que a propensão a inventar histórias (pecados), e a criar um mundo imaginário encarnando personagens romanescas, vai pari passu, "à veneração entusiasta das mulheres ilustres e infelizes." (p. 54)

Compreende-se que um convento não é o local mais adequado para se dar vazão às excitações de uma moça que, como se diz, está na flor da idade. Mas, as canções, as histórias e os romances trazidos pela solteirona de antiga família fidalga, encontraram terreno fértil na jovem Emma, em quem, "as comparações de noivo, de esposo, de amante celeste e de casamento eterno que se repetem nos sermões provocam-lhe no fundo da alma doçuras inesperadas" (p. 52). Isso se dá quando Emma tem por volta de quinze anos.

A estada de Emma no convento se encerra após a morte da mãe, seguida de curto período de luto teatralizado, que parece, na verdade, dar ocasião ao surgimento de uma rebel- 
dia e indisciplina que levaram Rouault, o pai, a retirá-la do internato.

A volta para casa lança Emma na depressão: "ela se considerava grandemente desiludida, nada mais tendo para aprender, não tendo mais nada para sentir" (p. 56).

É forçoso aqui evitar interpretações apressadas: afinal, é pouco o que temos, nada da infância. Mas o que nos evoca este trecho, "Ao voltar para casa, Emma comprazeu-se no comando dos empregados, em seguida, desgostou-se do campo e sentiu falta do convento." (p. 56), senão que é bom ocupar o lugar da mãe, embora o conflito edipiano e a culpa sejam intoleráveis e, então, seria melhor voltar para o seio da santa madre Igreja? O andamento do nosso trabalho nos mostrará se tal interpretação deve ser mantida ou alterada. Mas, é justamente aqui que aparece Charles Bovary na vida de Emma, para salvá-la, como o fará tantas outras vezes.

Charles é chamado à casa dos Bertaux para consertar a perna quebrada de Rouault, pai de Emma, e aí começa o flirt enquanto Charles ainda é casado com uma viúva que acaba falecendo, oferecendo-se, assim, a ocasião para a aproximação definitiva de Emma, com quem se casará. Novamente Emma ocupará o lugar de uma morta e, novamente, se comprazerá em cuidar da casa e em comandar os empregados. Mais do que isso,

a ansiedade de um novo estado ou talvez a excitação causada pela presença daquele homem bastara para fazer-lhe acreditar que possuía, enfim, a paixão maravilhosa que até então era considerada como um grande pássaro de plumagem rósea planando no esplendor dos céus poéticos (pp. 56-57).

A paixão é a paixão que a agora Madame Bovary precisa, sempre quis, e dela se alimenta; é ela que dá sentido à sua vida, dela depende como de uma droga. E é pela falta dela, no casamento com Charles, que esta relação definhará. Mas paixão pelo quê, por quem?

Charles era homem sem grandes atrativos, tanto físicos quanto espirituais; na verdade, era mesmo medíocre sob muitos aspectos. Então, o que Emma vê nele ou, pelo menos, tenta ver? É ela mesma, é sua própria imagem, sua própria paixão que ela busca ver em Charles, que se torna, então, o Outro de quem virá seu grande amor. Mas, logo após a noite de núpcias, a expectativa não se cumpre:

Antes de casar ela julgara ter amor, mas como a felicidade que deveria ter resultado daquele amor não viera, ela deveria ter-se enganado, pensava. E Emma procurava saber o que se entendia exatamente, na vida, pelas palavras "felicidade", "paixão", "embriaguês", que lhe haviam parecido tão belas nos livros (p. $51)$.

Sem o amor que esperava, o tédio e a frieza começam a tomar conta de seu relacionamento com o marido:

Se Charles o tivesse desejado, todavia, se o tivesse suspeitado, se seu olhar por uma única vez tivesse ido ao encontro de seu pensamento, parecia-lhe que uma abundância súbita ter-se-ia destacado de seu coração como cai a colheita de uma espaldeira ao ser sacudida. Mas, à medida que se estreitava mais a intimi- dade de suas vidas, realizava-se um afastamento interior que a desligava dele (p. 58).

Não que Charles não fosse bom marido: ele era gentil e atencioso, mas era comum demais, nem de longe se parecia com as personagens dos romances que Emma havia lido, apesar das tentativas em que ela buscava atiçar o fogo da paixão em si mesma e no marido,

Todavia segundo teorias que julgava boas, quis entregar-se ao amor. Ao luar, no jardim, recitava todas as rimas apaixonadas que sabia de cor e cantava, suspirando, alguns adágios melancólicos; mas sentia-se em seguida tão calma quanto antes e Charles não parecia nem mais apaixonado nem mais perturbado." (p. 60) "Emma repetia para si mesma: - Por que, meu Deus, eu me casei? (p. 61).

A paixão era o falo que Emma desejava hirto e fulgurante em si mesma e no Outro, que, por não se personificar no marido, tornou-o tão desinteressante e odiável quanto sua própria vida e até a si mesma. Mas, um acontecimento extraordinário vem salvar Madame Bovary da depressão e do tédio em que começava a mergulhar. Ela e o marido são convidados ao castelo de Vaubyessard pelo Marquês d'Andervilliers, que fora atendido por Charles. Lá, no meio de damas e cavalheiros, ela se refaz da pequenez da vida na província, valsando nos braços de um Visconde: "diante das fulgurações da hora presente, sua vida passada, tão nítida até então, desvanecia-se lá; além disso, ao redor do baile não havia mais do que sombra estendida sobre todo o resto" (p. 69).

As lembranças daquele baile alimentaram Emma durante vários meses até que a insatisfação e o tédio voltaram a assediá-la, os quais, ela tentava compensar com a leitura de romances e de revistas sobre Paris,

Passou a assinar a Corbeille, jornal das mulheres e o Sylphe des Salons. Devorava, sem nada esquecer, todos os relatos das primeiras representações, das corridas e dos serões, interessava-se pela estréia de uma cantora, pela abertura de uma loja. Conhecia as novas modas, o endereço dos bons alfaiates, os dias do Bois ${ }^{4}$ ou da Ópera. Estudou em Eugène Sue ${ }^{5}$ descrições de mobiliários; leu Balzac e George Sand, procurando em suas obras satisfações imaginárias para seus desejos pessoais. Trazia seu livro mesmo à mesa e virava as páginas enquanto Charles comia e lhe falava. A lembrança do visconde voltava sempre em suas leituras. Ela estabelecia relações entre ele e os personagens inventados. (pp. 74-75),

ou através de caprichos domésticos:

Ela o encantava com grande número de delicadezas; ora era uma nova maneira de fazer arandelas de papel para as velas, um babado que mudava em seu vestido ou o nome extraordinário de um prato bem simples que a empregada não acertara, mas que Charles engolia até o fim com prazer. Viu em Rouen senhoras que usavam um feixe de berloques presos ao relógio; ela comprou berloques. Quis para a lareira dois grandes vasos de vidro azul e, algum tempo depois, um estojo de marfim com um pouquinho de prata dourada (p. 77). 
Contudo, a insatisfação de Emma persistia e, já não encontrando o que pudesse preencher seu vazio, sua falta, aumentavam o desânimo e o desespero:

Agora negligenciava tudo em casa e a Sra. Bovary mãe, quando foi passar em Tostes uma parte da quaresma, surpreendeu-se muito com aquela transformação. Era, realmente, tão cuidadosa outrora e tão delicada, ficava agora dias inteiros sem se vestir, usava meias de algodão cinzentas e alumiava-se com uma vela (p. 82).

Então o corpo começou a falar:

Empalidecia e tinha palpitações; Charles administrou-lhe valeriana e banhos de cânfora. Tudo o que se tentava parecia irritá-la ainda mais. Certos dias conversava com uma abundância febril; àquelas exaltações sucediam, de repente, torpores em que permanecia sem falar, sem mover-se. O que a reanimava, então, era derramar nos braços um frasco de água de Colônia. (p. 83)

"A partir de então, ela começou a beber vinagre para emagrecer, contraiu uma tosse seca e perdeu completamente o apetite" (p. 84).

Com as reclamações freqüentes que Emma fazia de Tostes, vilarejo próximo à quinta de seu pai, e, após a recomendação de mudança de ares feita pelo antigo mestre que Charles consultou em Rouen, decidiram se instalar em Yonville, Neufchâtel.

Quando saíram de Tostes, Emma Bovary estava grávida e desejou ter um filho homem:

...ele seria forte e moreno e se chamaria Georges; e a idéia de ter um filho homem era como a esperança de compensação de todas as suas impotências passadas. Um homem pelo menos é livre; pode percorrer as paixões e os países, atravessar os obstáculos, agarrar a mais longínqua felicidade. Mas uma mulher é continuamente impedida. Inerte e flexível, ao mesmo tempo, tem contra si a languidez da carne com as dependências da lei.(p. 106)

Vê-se que a idéia que Madame Bovary tem do homem é a do falo potente e não a do simples macho, inversamente proporcional à imagem de castrada que faz de sua filha quando esta nasce: "- É uma menina! disse Charles. Ela virou a cabeça e desmaiou.” (p. 107) Mas, novamente, ela encontra em Yonville uma outra compensação, que é Léon, um jovem escrevente com quem compartilha o gosto pelos romances:

- Minha mulher pouco faz jardinagem, disse Charles; embora se lhe recomende fazer exercícios, prefere sempre ficar no quarto lendo.

- É como eu, replicou Léon; que há de melhor, realmente, do que ficar à noite do lado do fogo com um livro, enquanto o vento bate nos vidros, enquanto a lâmpada queima?...

- Não é verdade? disse ela, fixando nele os grandes olhos negros bem abertos (p. 101).

Léon apaixona-se logo por Emma, que não esconde seu interesse pelo rapaz, prodigando-lhe presentes e fazendo passeios juntos, às vistas de todos. E embora Charles perma- neça indiferente, "a senhora Tuvache, mulher do prefeito, declarou diante de sua criada que a senhora Bovary se comprometia." (p. 109), e mais: "por que a mulher do médico, dava ao escrevente tais generosidades? $\mathrm{O}$ fato pareceu divertir e todos pensaram definitivamente que ela devia ser sua amiguinha." (p. 118) E, num jogo de provocação e sedução, ela enredava-se a si e a Léon numa mistura de desejo e culpa, de aproximações e afastamentos, em que os dois, ao mesmo tempo, gozavam e sofriam: "Ele se torturava para descobrir como poderia fazer-lhe sua declaração; e, sempre hesitando entre o temor de desagradar-lhe e a vergonha de ser tão pulânime, chorava de desânimo e de desejo." (p. 118)

Nela, quanto mais o desejo crescia, mais virtuosa queria parecer:

...Não tenho a casa para dirigir, meu marido para cuidar, mil coisas enfim, muitos deveres que têm a primazia? (p. 123); Retirou Berthe da casa da ama-de-leite. Félicité trazia-a quando vinham visitas e a Sra. Bovary a despia a fim de mostrar seus membros. Declarava que adorava crianças; (p. 124); Quando Charles voltava, encontrava suas pantufas aquecendo-se junto às cinzas. Seus coletes, agora, tinham sempre forro e suas camisas tinham sempre botões...(p. 124)

Embora Emma lutasse contra seu desejo,

...mais Emma percebia seu amor, mais o recalcava, a fim de que ele não se evidenciasse e para diminuí-lo" (p. 125), "não conseguia frear seus sentimentos nem abdicar de sua paixão sofrida, [...],os apetites da carne, a ambição do dinheiro e as melancolias da paixão, tudo confundia-se num mesmo sofrimento; e, em lugar de desviar seu pensamento, agarrava-se mais a ele, excitando a dor e procurando em toda parte ocasiões para excitá-lo (p. 126).

E, na mesma medida em que todo seu amor se voltava para Léon, seu ódio alcançava Charles, a quem culpava por sua infelicidade e insatisfação: "Não era ele o obstáculo para qualquer felicidade, a causa de toda miséria e como o bico pontudo daquela fivela, daquela correia complexa que a fechava de todos os lados? (p. 126).

Como veremos adiante, nesta relação em espelho entre Léon e Madame Bovary, dá-se a impressão que a insatisfação é aquilo mesmo que se busca, pois mantém, no horizonte, o gozo absoluto:

Porém, com aquela renúncia, ele a colocava em condições extraordinárias. Ela desprendeu-se, para ele, das qualidades carnais das quais nada iria obter; e, em seu coração, ela foi sempre subindo e desligando-se à maneira magnífica de uma apoteose que levanta vôo. Era um daqueles sentimentos puros que não atrapalham o exercício da vida, que se cultivam porque são raros e cuja perda traria mais aflição do que a alegria que poderia trazer a posse. (p. 124)

Emma, depois de uma confissão frustrada aos ouvidos insensíveis do padre local, quando Léon partiu para Rouen, "teve vontade de correr para alcançá-lo, para atirar-se em seus braços e dizer-lhe: 'Sou eu, eu sou tua!' Mas Emma embaraçava-se antecipadamente com as dificuldades da em- 
presa e seus desejos, agravados pelo arrependimento, tornavam-se ainda mais ativos" (p. 141).

Léon seja porque, tal como o menino assustado, foge diante da presença da mãe sedutora, seja porque "estava cansado de amar sem resultado;" (p. 135), resolve continuar seus estudos de advocacia em Rouen. Então, "os maus dias de Tostes recomeçaram" (p. 141). Depois de tentativas frustradas de aprender italiano e de, somente, iniciar novas leituras, suas fraquezas voltaram: "Um dia mesmo escarrou sangue" (p. 142).

Mas, o destino ou o autor não deixam de providenciar novas aventuras para nossa heroína. Rodolphe Boulanger, um bon vivant que morava num castelo recém-adquirido nas proximidades da vila, leva um campônio para consultar-se com Charles e, à vista de Emma, resolve seduzi-la.

Aproveitando-se de um comício que se realizava em Yonville, Rodolphe aproxima-se de Emma com frases insinuantes, fazendo-se de amargurado e precisando de conforto: "Sim! Tantas coisas me faltaram! Sempre sozinho! Ah! Se tivesse tido uma finalidade na vida, se tivesse encontrado um afeto, se tivesse encontrado alguém" (p. 156).

Ao final do comício, Rodolphe já havia conseguido realizar parcialmente seu intento e, segurando as mãos de Madame Bovary, dizia: “ - Oh! Obrigado! A senhora não me repele! A senhora é boa! Compreende que lhe pertenço! Permita que a veja, que a contemple!” (p. 165).

Após um período de ausência estratégica, ele volta a visitar a casa de Emma e, propondo um passeio a cavalo, que é incentivado pelo próprio marido Charles, Rodolphe finalmente consegue que ela se entregue: "em prantos, com um longo frêmito e escondendo o rosto, ela se abandonou." (p. 177) Depois, como se estivesse, finalmente, realizando as fantasias da puberdade,

Lembrou então as heroínas dos livros que lera e a legião empírica daquelas mulheres adúlteras pôs-se a cantar em sua memória com as vozes das irmãs que a encantavam. Ela mesma tornava-se como uma parte real daquelas imagens e realizava o longo devaneio de sua juventude vendo-se como aquele tipo de amante que tanto desejara ser (p. 178).

Como num grito de vitória, dizia para si mesma: "Tenho um amante! Um amante!” (p. 178), que poderíamos traduzir: "Tenho um falo! Um falo!"

A partir daí, os encontros multiplicaram-se: na casa de Rodolphe ou mesmo, à noite, sob o caramanchão da casa de Emma, quando Charles dormia.

Aliás, ela tornava-se bem sentimental [...], falava-lhe de sua mãe e da mãe dele. Rodolphe a perdera havia vinte anos. Emma, contudo, consolava-o com linguagem afetada como se teria feito com um menino abandonado e dizia-lhe mesmo às vezes, olhando a lua: “-Tenho a certeza de que, lá em cima, elas aprovam nosso amor" (p. 185).

Entretanto, as bênçãos maternas, imaginadas por Emma, não foram suficientes, e Rodolphe, já se cansando de seu brinquedo, não era o mesmo: "o grande amor de ambos em que ela vivia mergulhada, parecia diminuir como a água de um rio que era absorvida em seu próprio leito, e ela percebeu o lodo" (p. 186).

A raiva e a humilhação fizeram com que se afastasse de seu amante; seus impulsos maternais voltaram-se novamente para a filha:

...percebendo que ela tinha a ponta das orelhas um pouco sujas, tocou a campainha para ter água quente e limpou-a, trocou-lhe a roupa de baixo, as meias, os sapatos, fez mil perguntas sobre sua saúde como se voltasse de uma viagem e enfim, beijando-a mais uma vez e chorando um pouco, recolocou-a nas mãos da criada muito admirada diante daquele excesso de ternura ( $\mathrm{p}$. 188)

Os valores e os costumes da época de Madame Bovary impedem-na de trocar de marido; o remédio que ela encontra, então, é fazer de seu marido um outro homem, fazer dele seu próprio falo. Há um aleijado em Yonville, Hippolyte. Charles poderia concertar-lhe a perna torta, seria um grande e inédito feito. Emma convence o marido a fazer a arriscada operação, sonhando com a glória do esposo, que seria sua própria glória e felicidade. A felicidade de ter o falo capaz de concertar o aleijado que, para Emma, é o reflexo de sua própria anomalia, pois é assim que ela mesma se sente: um ser em que algo não está direito, não está reto.

Novamente, as esperanças de Emma se frustram, o fracasso do marido na operação lança-a, outra vez, de encontro à sua falta e, definitivamente, nos braços de Rodolphe:

\footnotetext{
A lembrança do amante voltava a ela com atrações vertiginosas; nela lançava sua alma, levada para aquela imagem por um novo entusiasmo; e Charles parecia-lhe tão afastado de sua vida, tão ausente para sempre, tão impossível e aniquilado quanto o seria se fosse morrer e se estivesse agonizando sob seus olhos (p. 200).
}

Madame Bovary e Rodolphe voltaram a encontrar-se, mas, para ela, isso não bastava: ela queria ser a única, ser exclusiva, fugir com Rodolphe, romper com sua vida medíocre e encontrar a felicidade total. Rodolphe pressentia a voracidade de Emma, temia ser engolfado por ela: "Além do chicote com castão de prata dourada, Rodolphe recebera um sinete [...], tais presentes o humilhavam. Recusou vários; ela insistiu e Rodolphe acabou por obedecer achando-a tirânica e por demais invasora" (p. 205) .

Por isso, parte, sem Emma, que, enganada, fica a esperálo, inutilmente, com montes de vestidos-falo comprados, através de promissórias, ao inescrupuloso comerciante Lheureux, que já a enredara noutras tantas.

É o fim e, após ler a carta, "Estarei longe quando você ler estas tristes linhas" (p. 217); "deu um grito e caiu hirta, de costas, no chão.” (p. 221). Emma quis morrer, mas o marido, abnegado, salva-a e ampara-a durante o longo tempo em que ela, de certo modo, morrerá: "Durante quarenta e três dias Charles não se afastou [...], pois ela não falava, não ouvia nada e parecia mesmo não sofrer, como se seu corpo e sua alma descansassem juntos de todas as suas agitações" (p. 223). 
Emma se faz de morta para o mundo que a rodeia, para o marido, para a filha, para tudo. Duas coisas a mantêm viva: os cuidados de Charles e as fantasias dela, que permaneceram no recôndito de seu ser, mesmo durante curto período de fé religiosa,

Quando se ajoelhava no genuflexório gótico, dirigia ao Senhor as mesmas palavras de suavidade que murmurava outrora ao amante nas efusões do adultério. Era para provocar a fé; mas nenhum deleite descia dos céus e ela levantava-se novamente, com os membros cansados, com um vago sentimento de um imenso logro (p. 228-229),

até reacenderem-se novamente, quando o marido a leva a Rouen para assistir à ópera. Lá reencontram Léon.

Sob o pretexto de que desejava assistir à segunda parte da ópera, Emma fica em Rouen sob os cuidados de Léon, enquanto Charles, para atender seus pacientes, parte para Yonville. Começa aí outra aventura de Madame Bovary.

Léon, que, durante sua estada em Rouen, adquirira certa autoconfiança, depois de se fazer de amargurado, tal como Rodolphe, e dizer que tinha querido morrer, finalmente declara-se: " - Porque eu a amei muito!" (p. 251).

Depois de longo e vertiginoso passeio de carruagem, no interior da qual se entregam lubricamente, "com os estores fechados e que aparecia assim continuamente, mais fechada do que um túmulo e sacudida como um navio" (p. 261), instalam-se num quarto de hotel em Rouen e, através de inúmeras escapadas, enquanto Charles atende seus distantes pacientes, vivem seu sonho de amor: "Estavam tão completamente perdidos na posse mútua que se sentiam em sua própria casa como se lá tivessem de viver até a morte como dois eternos jovens esposos” (p. 280). Ela lhe dizia: “- Criança tu me amas? E quase não ouvia sua resposta na precipitação com que seus lábios lhe procuravam a boca." (p. 281).

No entanto, a realidade começa a esgueirar-se para dentro do sonho de Madame Bovary. E às custas de mais promissórias e mentiras, mantém seu amor maníaco: "Ela riu, chorou, cantou, dançou, mandou buscar sorvetes, quis fumar cigarros" (p. 290)

Léon vê seu ser esvair-se naquela relação: "O que o encantava outrora assustava-o um pouco agora. Aliás revoltava-se contra a absorção, cada vez maior, de sua personalidade" (p. 297).

A voracidade de Madame Bovary acompanhava-se de permanente insatisfação: "ela não era feliz, nunca o fora [...] cada sorriso escondia um bocejo de tédio, cada alegria uma maldição, qualquer prazer um desgosto e os melhores beijos deixavam nos lábios apenas um irrealizável desejo de uma maior volúpia” (p. 298).

Além disso, os vultosos gastos de Emma começam a ser cobrados pelo comerciante que, durante tanto tempo, sustentou seus desejos e sonhos. Sem dinheiro, ela recorre a Léon, a quem chega a propor um roubo no cartório em que ele trabalhava.

Acossada pelas ameaças de Lheureux, que vendera suas promissórias para outro comerciante, igualmente inescrupuloso, o qual pretendia mover ação judicial para ar- rematar a casa de Emma como paga de suas dívidas, desespera-se nossa personagem ao ver-se insultada com as propostas libidinosas do notário da cidade: "Sou digna de pena mas não estou à venda!" (p. 318).

Mas, em seguida, oferece-se ao preceptor Binet, que a repele: " - Senhora! Como pode pensar!” (p. 321).

Tudo isso não era pior do que se render a Charles: "A idéia da superioridade de Bovary em relação a ela a exasperava" (p. 319).

Parece-nos mesmo que Charles sempre representou o Outro (o pai-ideal), a quem ela buscava sempre diminuir, sobrepondo-se a ele, como a seus amantes, tratando-os como crianças tolas, como objetos.

Como derradeiro recurso, Emma procura Rodolphe, que havia voltado para seu castelo, e se queixa, então, para o outro Outro:

\footnotetext{
...eu ter-te-ia dado tudo, teria vendido tudo, teria mendigado nas estradas, por um sorriso, por um olhar!...depois, quando volto para ele, para ele que é rico, feliz, livre! Para implorar um socorro que qualquer pessoa daria, suplicando e trazendolhe toda a minha ternura, ele me repele, porque isso lhe custaria três mil francos! (p. 326).
}

Diante das súplicas dela, Rodolphe despreza-a e lhe diz que ele não tem a soma que pede. Emma vê-se de frente com a falta, a falta que ela tanto quis preencher; torna-se falta de tudo: de dinheiro, de respeito, de amor. Finalmente, só uma coisa pode preencher essa falta de tudo, a morte. Emma procura, no arsênico, a morte que porá fim à sua busca incessante, busca daquilo que não existia e que, portanto, nunca seria encontrado.

Mesmo em relação ao suicídio e à morte, Emma Bovary se engana: “ - Ah! A morte é bem pouca coisa, pensava ela: vou dormir e tudo estará acabado!” (p. 329).

Nela esperava encontrar a paz, o sono eterno, a satisfação completa que só é possível no não-desejar. Na verdade, Madame Bovary tem morte horrível: "punha-se a gritar horrivelmente. Amaldiçoava o veneno, injuriava-o, suplicava que se apressasse" (p. 333).

No suplício de sua dor, goza. E de que gozo se trata? Do gozo do Outro? Citaremos do artigo Deseo y Goce en la Histérica de Catherine Millot et al. (1987/1985), o seguinte trecho: Fuente última de resistencia, el superyó rehúsa hasta el final ceder el goce del síntoma: más bien enfermedad, depresión, a veces intervenciones quirúrgicas, la muerte misma (p. 130).

Finalmente, "Uma convulsão abateu-a sobre o colchão. Todos se aproximaram. Ela não mais existia” (p. 340).

Emma Bovary não é uma histérica dos tempos de Charcot ou do Freud do início da psicanálise, não sofria freqüentemente de grandes ataques, não tinha paralisias, nem anestesias. Mas, tinha seus desmaios e, em suas crises, anorexias e estados próximos da catalepsia. Embora Freud e Flaubert tenham sido praticamente contemporâneos (final do séc. XIX), talvez coincidentemente com o caráter mutativo de sua obra, sua personagem parece-nos um tipo de histeria intermediário, que, ape- 
sar de seus trajes ridículos, pelo menos na sintomatologia, está entre as grandes histéricas charcotianas e as modernas "personalidades" histéricas.

A histeria foi despojada. Ela perdeu seus trajes ridículos, estranhos, desconcertantes; aqueles que, aos olhos dos médicos, constituíam seu atrativo e charme. A auréola misteriosa e maravilhosa que a circundava desde a Antiguidade se dissipou. Despojada de seus sintomas, nada mais resta da histeria senão ela mesma: uma personalidade histérica. (Trillat, 1986/1991, p. 281, 282).

Poderia se objetar que, no fim das contas, tal como a personagem, a histeria de Flaubert é uma ficção e que, portanto, não vale a pena debruçar-se sobre ela.

Mas, o escritor é como um "catalisador cultural":

...não é esta mônada isolada que poderia reinvidicar para ele só o que produz; como todos, é o resultado de uma série de desejos escalonados sobre várias gerações e o fruto de um momento cultural preciso. Em seguida, utiliza uma língua carregada de sentidos que o domina e o submete mais freqüentemente do que pensa (Willemart, 1993, p. 26)

Além disso, utilizamo-nos do exemplo de Freud, que recorreu freqüentemente aos poetas, tais como Jensen e Goethe, entre outros, para ilustrar suas idéias e conceitos.

Precavendo-nos com Hegel, segundo o qual, a resposta à pergunta pode estar na própria pergunta, ou seja, que a estrutura da histeria pode estar na sua aparência mesma, ou mesmo naquilo que a oculta, entramos em cheio num daqueles elementos ou aspectos mais evidentes da estrutura da histeria na obra de Flaubert, que é a insatisfação.

Madame Bovary busca em seu marido e em seus amantes a felicidade ou, poderíamos dizer, o falo, a completude, que nunca consegue alcançar, deparando-se sempre com a castração que aparece no(s) Outro(s) quando este(s) não correspondem às suas expectativas. No entanto, há aí um gozo, que é o que o neurótico satisfaz quando sofre,

Eles satisfazem algo que vai sem dúvida ao encontro daquilo com o que eles poderiam satisfazer-se, ou talvez melhor, eles dão satisfação $a$ alguma coisa. Eles não se contentam com seu estado, mas, estando nesse estado tão pouco contentador, ele se contentam assim mesmo. (Lacan, 1964/ 1990, p. 158).

Estamos no campo das aparências ou da estrutura? Implicada neste gozo da insatisfação está sempre sendo remetida mais adiante, até mesmo na morte, a própria castração, a falta, dela mesma, Madame Bovary.

A insatisfação também aparece enquanto tema em outras obras de Flaubert, como em Educação Sentimental (1959), romance que se supõe autobiográfico, que narra a trajetória sentimental do jovem Frederico apaixonado pela Madame Arnoux, mulher casada que também ama Frederico, mas que permanece fiel ao marido, impondo a si mesma e ao herói do romance estado irremediável de insatisfação.

Esta obra, com forte colorido edipiano, parece mesmo uma apologia da falta e da insatisfação a que o homem está condenado tentar preencher de infinitas maneiras. O herói percorre, do início ao fim do romance, toda uma plêiade de situações de amizade, amor, sexo, banquetes, revoluções sociais que, no fim, dão em nada, pelo menos nada que se pareça com o que se prometia para o jovem Frederico no início. $\mathrm{O}$ que lhe sobra é um único amigo, com quem reparte suas recordações. Percebe-se que o próprio rapaz, em função de sua fantasia impossível com Madame Arnoux, persegue seu fracasso.

É do fracasso e da insatisfação que também trata o último e inacabado livro de Flaubert, Bouvard e Pécuchet (1981), no qual um dentre dois amigos, logo depois de se conhecerem, é premiado por vultosa herança que é totalmente dilapidada em iniciativas e projetos, em quase todos os campos do conhecimento e da indústria humana, todos fracassados.

Flaubert, que permaneceu fiel a um amor impossível da juventude e que, durante boa parte da vida, se isolou do contato social para dedicar-se à produção de sua obra, parece-nos ter feito de sua própria insatisfação, de sua própria falta, a razão de seu gênio.

\section{Referências}

Flaubert, G. (1959). Educação sentimental: história de um moço. São Paulo: Difel. Flaubert, G. (1981). Bouvard e Pécuchet. Rio de Janeiro: Nova Fronteira.

Flaubert, G. (1993). Madame Bovary. São Paulo: Nova Alexandria (Texto original publicado em 1857)

Freud, S. (1973). Proyecto de una Psicologia para neurologos. In Obras completas de Sigmund Freud (v. 1, $3^{\mathrm{a}}$ ed.). Madrid: Biblioteca Nueva (Texto original publicado em 1895).

Freud, S. (1973). Estudios sobre la histeria. In Obras completas de Sigmund Freud (v. 1, $3^{\mathrm{a}}$ ed.). Madrid: Biblioteca Nueva (Texto original publicado em em 1895).

Freud, S. (1973). La etiologia de la histeria. In Obras completas de Sigmund Freud (v. 1, $3^{\mathrm{a}}$ ed.). Madrid: Biblioteca Nueva (Texto original publicado em 1896).

Freud, S. (1973). La sexualidad en la etiologia de las neurosis. In Obras completas de Sigmund Freud (v. 1, $3^{\mathrm{a}}$ ed.). Madrid: Biblioteca Nueva (Texto original publicado em 1898).

Freud, S. (1973). Analisis fragmentario de una histeria (Caso Dora). In Obras completas de Sigmund Freud (v. 1, $3^{\mathrm{a}}$ ed.). Madrid: Biblioteca Nueva (Texto original publicado em 1905).

Freud, S. (1973). Fantasías histéricas y su relación con la bisexualidad. In Obras completas de Sigmund Freud (v. 2, $3^{\mathrm{a}}$ ed.) Madrid: Biblioteca Nueva (Texto original publicado em 1908).

Freud, S. (1973). Pegan a un niño. Aportación al conocimiento de la génesis de las perversiones sexuales. In Obras completas de Sigmund Freud (v. 3, $3^{\mathrm{a}}$ ed.). Madrid: Biblioteca Nueva (Texto original publicado em 1919).

Freud, S. (1973). Sobre la psicogénesis de un caso de homosexualidad femenina. In Obras completas de Sigmund Freud (v. 3, $3^{\mathrm{a}}$ ed.). Madrid: Biblioteca Nueva (Texto original publicado em 1920).

Freud, S. (1973). La disolución del complejo de Edipo. In Obras completas de Sigmund Freud (v. 3, $3^{\mathrm{a}}$ ed.). Madrid: Biblioteca Nueva (Texto original publicado em 1924).

Freud, S. (1973). Algunas consecuencias psíquicas de la diferencia sexual anatómica. In Obras completas de Sigmund Freud (v. 3, $3^{\mathrm{a}}$ ed.). Madrid: Biblioteca Nueva (Texto original publicado em 1925).

Freud, S. (1973). Sobre la sexualidad feminina. In Obras completas de Sigmund Freud (v. 3, $3^{\mathrm{a}}$ ed.). Madrid: Biblioteca Nueva (Texto original publicado em 1931).

Freud, S. (1973). Nuevas lecciones introductorias al psicoanalisis - la feminidad. In Obras completas de Sigmund Freud (v. 3, $3^{\mathrm{a}}$ ed.). Madrid: Biblioteca Nueva (Texto original publicado em 1933). 
Lacan, J. (1998). Intervenção sobre a transferência. In Escritos. Rio de Janeiro: Jorge Zahar (Texto original publicado em 1951).

Lacan, J. (1990). O Seminário Livro 11 os quatro conceitos fundamentais da psicanálise. Rio de Janeiro: Jorge Zahar (Texto original publicado em 1964).

Lacan, J. (1985). O Seminário Livro 20 mais, ainda. Rio de Janeiro: Jorge Zahar (Texto original publicado em 1975).
Millot, C., Blancard, M. H., Broca, R., Godin, J. G., Hamon, M. C., Léres, G., Naveau, P., Pomier, G., Tardits, A, \&.Vaças, P. (1987). Deseo y goce en la histérica. In Histeria y Obsesion (pp. 126-130). Buenos Aires: Manantial (Texto original publicado em 1985) ${ }^{6}$.

Trillat, E. (1991). História da histeria (P. Porchat, Trad.). São Paulo: Escuta (Texto original publicado em 1986).

Willemart, P. (1993). Universo da criação literária. São Paulo: Edusp.

\section{Nota}

1 Este artigo é uma versão modificada de parte de minha tese de doutorado A Estrutura da Histeria em Madame Bovary, inédita, São Paulo, USP, 1998.

2 A tradução é nossa.

3 "O autor, em sua obra, deve ser como Deus no universo: onipresente e invisível”, citação da orelha do livro "Madame Bovary: costumes de província", de Gustave Flaubert. (1993), tradução de Fúlvia M.L. Moretto, São Paulo: Nova Alexandria, do qual também foram extraídas todas as citações do texto "Madame Bovary" aqui presentes.

4 Dias de passeio no Bois Boulogne. (Nota do autor)

5 Eugène Sue (1804-1857), romancista francês, autor de Les Mystéres de Paris (1843), Mathilde (1841), Les Sept Péchés Capitaux (1847-1849). (Nota do autor).

6 A obra não apresenta os organizadores. Trata-se de tradução de texto original francês, Histérie et obsession, da Navarin Éditeurs, Paris, 1985, que reune os relatos preparados para o IV Encontro Internacional do Campo Freudiano, Paris, 1986. Contudo, na apresentação da obra em espanhol (p. 11), menciona-se a comissão de organização dos Encontros Internacionais da Argentina da Fundação do Campo Freudiano como responsável pela tradução dos textos: Diana Etinger de Alvarez, Juan Carlos Indart, Zulema Lagrota, Diana Rabinovich e Oscar Sawicke. O texto em questão foi traduzido por B. Udenio e está nas pp. 126-130.

Sérgio Scotti, psicanalista, doutor em Psicologia Clínica pela Universidade de São Paulo (SP), é professor do Departamento de Psicologia da Universidade Federal de Santa Catarina, SC.

Endereço para correspondência: Rua Alírio Bossle, 421, Saco Grande I, 88030-510, Florianópolis, SC. Tel. (048) 238-3380. E-mail: sscotti@mbox1.ufsc.br. 